\title{
Defending Vulnerable Workers in South Africa After the Crisis What Role for COSATU?
}

\author{
Freek B. Schiphorst \\ International Institute of Social Studies \\ The Hague - The Netherlands \\ October 2010
}

\section{Introduction}

The crisis did not spare South Africa. Whereas employment showed an increase till the last quarter of 2008, a plunge set in thereafter. The economy shrank by an estimated 1.8 per cent with mining and manufacturing particularly hard hit showing a decrease in output of seven and twelve per cent respectively (Gordhan 2010: 5). By the middle of 2010 over 1.1 million people lost their job since the beginning of 2009 (Statsa 2009 \& 2010: vi). Unemployment rose to $25.3 \%$ and if one includes the people who are discouraged from looking for a job, even to $36.5 \%$ (Statsa 2010: v; see also Verick 2010a).

Although there is an Unemployment Insurance Fund (UIF) its coverage is very uneven and the benefits small. ${ }^{1}$ Under such conditions rising unemployment and discouragement means that people have to resort to vulnerable types of jobs to secure their livelihood. This begs the question what vulnerable workers can expect from organised labour to give them voice and representation, if not something more tangible. This chapter will explore this question by looking at what COSATU has done to defend the interest of vulnerable workers in South Africa. I will first explore the size of the vulnerable workforce in South Africa. Then I will analyse official COSATU documents on its policy towards the informal economy. Then I will present two attempts to give voice to vulnerable workers in South Africa and examine the role played by the COSATU in each of them. These cases are: the Self Employed

\footnotetext{
${ }^{1}$ If a worker is registered and has contributed for four years to the UIF he/she can claim a maximum of $58 \%$ of a day's salary for 218 days (see http://www.capegateway.gov.za/eng/directories/services/7296/21273). Verick concludes: "...employment protection legislation (EPL) in South Africa is relatively weak. Thus, workers are neither provided protection of jobs through EPL nor protection of income via unemployment benefits (2010b:28).
} 
Women's Union (SEWU) and Sikhula Sonke, an independent trade union organising farm workers in the Western Cape. ${ }^{2}$

\section{Trade Unions and Vulnerable Workers in the Informal Economy?}

For quite some time now, trade union leaders, policy advisers and organisers the world over are concerned with the growing importance of informal work and the decline of formal sector employment (see e.g. Adu-Amankwah 1999). This concern has many facets: a loss of membership and resources is certainly one, but not the only one. The representativeness of the trade union movement became also an issue; with the dramatic decline in formal sector employment what claim could the trade union have to be "the voice of working people" if it only was engaged with formal work? Finally, with the often degrading conditions of work in the informal economy notions of labour solidarity played a role. After all, an injury to one remains an injury to all. So, despite a few odds (elaborated below), a trade union seems to be an obvious candidate to redress the voice deficit of the working poor in the informal economy.

There are at least three arguments that seemingly stop trade unions from engaging constructively with (and for) vulnerable workers in the informal economy. Traditional views have it that a union should only organise wage workers, and since workers in the informal economy often are own account workers these count as entrepreneurs. An equally antiquated view holds that a trade union should first organise completely the formal sector and only once that has been achieved turn its attention to workers in the informal economy. The view is antiquated, not only because it totally ignores the basic tenet of worker organisation (i.e. labour solidarity) but also because -as in the case of South Africa - it is based on the outdated view that the informal economy is small in size and does, therefore, not yet need the full attention of the trade union. We shall return to question of size shortly.

A third objection is more difficult to counter, since it is not based on dogma but on unruly reality. Some fear that by organising the working poor the interests organised by a trade union become too heterogeneous. These diverse interests might now even

\footnotetext{
${ }^{2}$ Fieldwork was undertaken in South Africa in October-November 2006. Subsequent interviews were held in Harare in February 2010 with officials of the Zimbabwe Congress of Trade Unions.
} 
become directly opposing; suppose a union would organise both the workers in a large factory as well as the working poor in the small and micro establishments with whom this large firm has cut-throat contracts to supply it with parts and half-products. Any improvement in the condition of these working poor will directly be debited to the wages and conditions of the union members in the large firm. This is a zero-sum game: the gain of one is the loss of the other. And thus, it is argued, it is better not to bring such opposing interests into the fold of one organisation and complicate matters. Indeed, convincing existing trade union members of the need to extend union services to informal workers is a major obstacle. This is compounded by the fact that informal workers often are not able to meet the same subscription requirements that ordinary trade union members face (see Adu-Amankwah 1999).

We will turn to South Africa now and first sketch an overview of the magnitude of the phenomenon of the vulnerable workers there. The main focus in this paper is on COSATU, arguably one of the strongest and best endowed central labour organisations in Sub Saharan Africa (with the Nigerian Labour Congress as at least numerically stronger). With a membership of 1.8 million COSATU by far outnumbers the other national centres in the country ${ }^{3}$, and as a member of the national Tripartite Alliance -with ANC and SACP - it is close to the powers that be.

\section{Vulnerable Workers in South Africa: an overview}

Compared to other countries on the African continent the size of the informal economy is relatively small. Three-quarters of non-agricultural employment in Sub Saharan Africa is informal and over $90 \%$ of new jobs are in the informal economy. And with informal work I refer -following the ILO usage of the term- to work which is not registered, recognized or protected within legal and regulatory frameworks.

The following table shows the figures in the South African perspective (Statsa 2010:vi).

\footnotetext{
${ }^{3}$ NACTU (approx. 400,000 members in 2003), FEDUSA (approx. 515,000 in 2003) and CONSAWU (approx. 240,000 in 2006), see Schiphorst et al. 2007. These four federations (and 250 independent trade unions) had a union density in 2004 of close to $40 \%$. After the onset of the crisis this dropped to just under $30 \%$.
} 
Table 1. Key Labour Market Indicators June 2010

$\begin{array}{lr}\text { Population 15-64 } & 31,399,000 \\ \text { Total economically active } & 17,054,000 \\ \text { Total employed } & 12,742,000 \\ \text { Total unemployed } & 4,312,000 \\ \text { Discouraged work-seekers } & 1,907,000 \\ \text { Other not economically active } & 12,438,000\end{array}$

The employed are subdivided as follows (ibid.)

Table 2. Employed by Sector June 2010

$\begin{array}{lr}\text { Total employed } & 12,742,000 \\ \text { Formal (non-agric) } & 8,845,000 \\ \text { Informal (non-agric) } & 2,124,000 \\ \text { Agriculture } & 618,000 \\ \text { Domestic } & 1,155,000\end{array}$

At first glance, the number of the informally employed is less than $20 \%$ of total employment and thus far less than the average for Sub-Saharan Africa. However, this is misleading. In the absence of social security protection we have to assume that the unemployed as well as the discouraged work seekers will have to find some income in the informal economy. So, in search for vulnerable workers these categories have to be included. Furthermore, work in the domestic service as well as in agriculture is widely recognised as vulnerable (see e.g. King 2007; Vavi 2010) and, therefore, we have to add those categories as well. The picture thus emerging is presented in the following table.

Table 3. Vulnerable workers, June 2010 (,000)

\begin{tabular}{|c|c|}
\hline Total unemployed & $4,312(+92,152$ đ 2,160$)$ \\
\hline Discouraged work-seekers & $1,907(q 1,070$ ๙ \\
\hline Informal & $2,124$ (ㅇ 933 ○ 1,190$)$ \\
\hline Domestic & 1,155 (q $910 \hat{\jmath}$ \\
\hline Agriculture & $618\left(\begin{array}{ll}9 & 2140^{\lambda} \\
-1\end{array}\right.$ \\
\hline Vulnerable & $10,116(q 5,279$ o 4,835$)$ \\
\hline (Formal & $8,845)($ q 3,590 ठ 5,256 \\
\hline
\end{tabular}

(Statsa 2010:vi \& 2\&3; numbers are rounded off).

A narrow focus on people in informal employment obscures the magnitude of vulnerable workers. This could indeed easily create the impression that with a relatively small size the urgency is also small. This seems to be the picture that COSATU paints for its members. In its report to the Congress in 2006, COSATU's 
secretariat use phrases like "the share of informal employment has remained fairly stable since 1996" and "the decline compared to 1999" above a table which shows that the informal sector only has 23 percent of total employment (COSATU 2006:39). The reporting for the Congress in September 2009 is silent about its role in the informal economy and it now almost seems that the only type of vulnerable worker recognised by COSATU is the contract worker hired by labour brokers (see below).

\section{COSATU}

The first time COSATU is squarely confronted with the question what to do with vulnerable workers is when the September Commission tables its report to the Congress in 1997. In its chapter "New Workers, New Members: Organising New Sectors and New Layers of Workers", the report identifies two options regarding the "vulnerable sectors", the first one being:

COSATU could continue as it currently does [i.e. with no change]. The result could be weak affiliates in many vulnerable sectors. The affiliates that are currently strong and well-organised would remain so. But overall, COSATU's position in the labour market would be weakened, and this would be likely to affect its influence... (September 1997:6). ${ }^{4}$

The second option is carried by the particularly poignant vision regarding the role of a trade union vis-à-vis workers in the informal economy.

Most of those who work in the informal sector do so outside the protection of state regulation or union organisation. This makes them vulnerable to many different kinds of exploitation and oppression. Their weakness also impacts on the power and conditions of formal sector workers, weakening the position of trade unions in the labour market. Their plight therefore concerns COSATU, both from the point of view of promoting human rights and social justice in general, and from the point of view of protecting the strength of the trade union movement (September 1997:8).

The September Commission (1997:8) recommends in particular two options:

\footnotetext{
${ }^{4}$ The report is available on the internet, but its chapters are separately presented, hence page numbering starts anew with each chapter. Unless otherwise stated, the quotes of the September Commission Report are from chapter seven.
} 
1. encourage affiliates to expand their activities to include workers in informal sector activities in their industrial sectors;

2. encourage organisations of informal sector workers to affiliate to it or even initiate the formation of informal-sector affiliates.

The Commission urges COSATU to develop a strategy to encourage affiliates to extend its services to vulnerable workers. While it recognises that unions in these efforts may face financial problems - after all vulnerable workers are not able to contribute substantial dues the Commission recommends COSATU:

to develop a strategic focus on the vulnerable sectors. Strategies could include the internal transfer of resources from strong to weak affiliates... [and] ... a modest 'solidarity levy' could be levied on all affiliates... (1997:9).

The report of the September Commission is subsequently duly adopted by Congress as a guideline for the future direction of the COSATU (Bonner 2004:4). The Congress of COSATU in 2000 resolved that a special commission be established to prepare an organisational review. This high powered commission presents a report in 2001 to the First Central Committee of COSATU which calls for efforts to "... expand existing membership and to reach out to workers in non-standard jobs and the informal economy" (Transforming 2001:21). The report then proposes a two-pronged approach. On the one hand, it suggests (as "the best way") that the government takes the lead improving conditions for vulnerable workers. On the other hand the commission urges that a study explores the feasibility:

... of establishing service centres in the regions to reach out to workers in the informal sector as well as domestic and farm workers. Advice centres would both help reduce the cost of serving these workers, and let workers get help from unions even if vulnerability at work means they cannot join (Transforming 2001:22).

The Organisational Review report to the National Congress in 2003 is not very explicit on the extension to the informal economy or vulnerable workers. The closest it comes to an appeal to its affiliates to devote attention to these workers is couched in general terms as follows:

Given downsizing in the formal sector, recruitment is critical. Every affiliate should aim for $10 \%$ growth every year. In particular, we must ensure much higher density for COSATU unions in the formal sector, 
while continuing to support recruitment in the informal sector (Organisational 2003:22).

Rather than a two-pronged strategy for the long term, i.e. one in which simultaneously (vulnerable) workers in the formal and in the informal economy are targeted, it now seems that the focus is squarely put on recruitment in the formal sector.

Then NALEDI, COSATU's think tank, picks up the gauntlet. It sources funds for a review study and asks Chris Bonner - a well respected figure within COSATU- to produce an overview of the developments in organisational renewal. She writes a critical yet constructive report painfully showing the slow progress COSATU has made since the September report in 1997. Bonner observes that

Extending the boundaries beyond "traditional" membership type does not appear high on the agenda of many established affiliate organizational renewal programmes. Whilst the September Commission, as early a 1997, set out recommendations for organising workers in the informal sector, and COSATU Congress of 2000 set out a programme to do so, unions have not generally prioritized this in their organizational renewal programmes (2004:34).

Bonner explains how a few affiliates have gone some length to support workers in informal employment. She subsequently puts her finger on the crux of the matter:

...[the affiliates] have targeted "atypical" or "non-standard" workers in waged employment, such as casual and outsourced workers, workers employed through labour brokers and the like, rather than those who more clearly form part of the informal economy, such as street vendors (2004:34).

As for the role of COSATU in organisational renewal Bonner warns for a lackadaisical attitude. Despite the fact that seven years have passed since the September Commission pointed the way, and with two national Congresses since then urging the organisation to take an active stance, no progress could be reported. Her study is based on interviews with the leadership of the affiliates and from these she reports:

However, serious reservations have been expressed about the ability of COSATU and individual affiliates to successfully implement resolutions on organizational renewal and sustain the work, unless COSATU actively keeps it on the agenda, continuously "whips" affiliates into action, and provides more support for affiliates processes. Since the $8^{\text {th }}$ Congress it has failed to do this. COSATU leadership has influence, weight and 
authority with affiliates, which it is failing to maximize to promote and monitor affiliate organizational renewal work (Bonner 2004:61).

In February 2005 COSATU convenes a strategic planning workshop which decided that COSATU would launch a new trade union "for workers in the burgeoning informal economy (...) in a move aimed at boosting its stagnating membership" (Robinson 2005). The new union was to organise street vendors and producer groups, including home-based workers. It is clear from the two available reports of this meeting (Robinson 2005, and Horn 2005) that care had to be taken not to tread on toes of existing affiliates. The new union was only to deal with self-employed workers outside the scope of existing affiliates, and so it would not affect "workers in other sectors of the economy, including the taxi industry, construction and manufacturing, [who] will be absorbed into existing COSATU affiliates" (in Robinson 2005).

It was decided at the workshop that prospective members would pay dues but it was also reported that a COSATU official thought that "the new union will be supported financially by the foreign donors that sustained SEWU" (Robinson 2005). The workshop also agreed to have a dedicated National Co-ordinator to see to the implementation of the project (Horn 2005:2). A year passes and COSATU secretariat proposes the same to the Congress in 2006 (COSATU 2006: 42). Devenish and Skinner optimistically report that COSATU committed itself to "...assist in establishing a new informal economy union [which] may well hire former SEWU staff' (2006:256). Since then, little has been made public about this new project and by the middle of 2010 nothing had materialised yet. At the tenth national Congress of COSATU out of a total 129 resolutions covering a total of 188 pages, only one resolution deals with organising the unemployed and vulnerable workers. The resolution tabled by NUMSA calls on COSATU to "champion the struggle for vulnerable workers, by organising these workers and providing a service to them. The Department of Labour must assist in terms of resources for this to happen" (Final 2009: 141). ${ }^{5}$

\footnotetext{
${ }^{5}$ NUMSA is the National Union of Metal Workers in South Africa and proudly calls itself the $2^{\text {nd }}$ largest trade union in South Africa. It is remarkable that a trade union of this stature calls on the government to fund organisational renewal. It contrasts sharply with earlier calls for the stronger affiliates to assist the weaker ones. It is however, fully in agreement with the attitude that government should take the lead and/or should pick up the tab.
} 
Another topic of heated debate is the role of labour brokers. A long standing phenomenon in South Africa, it became a very topical issue when in November 2008 the Supreme Court in Namibia ruled that a ban on them was not against the constitution (see Ndungu 2009:9). Within a month the South African Minister of Labour pronounced that the ANC planned to ban labour brokers as well, a statement welcomed by the COSATU's spokesperson. Already in 2006 the Congress of COSATU had adopted resolutions for the federation to "combat the abuse by labour brokers" but no action was actually undertaken (in Ndungu 2009:8). Throughout 2009, COSATU rallies behind the Minister's call. At the Congress in 2009, four affiliates call for "stringent regulation, if not outright outlawing of the labour broker industry and practices" (Final 2009:79). Interestingly, the same resolution does not call on unions to step up their efforts to organise externalised workers. Instead the resolution calls on COSATU to fight for a change in the law that would convert "all temporary, contract and casual jobs into permanent quality jobs" (Final 2009:80).

All in all, one cannot escape the conclusion that COSATU is amply aware of the need to become engaged with informal work, both as a result of casualisation, informalisation and externalisation of formal workers and as a result of the growing number of people eking out a living without access to income out of the formal economy. However well aware, it does not seem that COSATU leadership is impressed with a sense of urgency. Despite repeated recommendations from its own think-tanks or resolutions from its own Congress. The result of such an approach can be seen in two cases to which we will now turn: the rise and fall of SEWU, and the experience of Sikhula Sonke.

\section{The Self Employed Women's Union - SEWU}

Easily the most cited example of organising workers in the informal economy in South Africa is the Self Employed Women's Union - SEWU (see Bennett 2003; Chenn et al. 2004; Devenish \& Skinner 2004, 2006, 2007; Kabeer 2008; Lund \& Skinner 1999, 2004; Motala 2002; Skinner 2000; Theron 2010). This is quite extraordinary for a movement that existed only ten years: established in 1994, it closed down in 2004. Let us have a closer look at the organisation. 
Inspired by the model set by SEWA in India, Pat Horn, a trade unionist of long standing in South Africa decides to organise women in the informal economy. According to SEWU's constitution membership was only open to women who were working without regular waged employment, were involved in an economic activity not covered by any other trade union and who did not employ more than three others (Bennett 2003:34). Although never registered as a trade union, SEWU's organisational model and practice are based on direct democracy (of workers controlling their own organisation) and its organisational form resembled that of a trade union (see Devenish \& Skinner 2006: 260-62).

SEWU's members are active at the lower end of the labour market in "survivalist activities", with incomes of members being very low. Where initially membership was drawn from street vending, this over time broadened to include also home-based work and small scale farming, for the major part in urban areas. The initial dominance of street vendors in its membership gave way over time to a dominance of homebased workers (Devenish \& Skinner 2004:17). After three years, in 1997, SEWU also opened offices in the Western Cape and in the Eastern Cape, and in 2001 offices are opened in two more provinces (Free State and Mpumalanga). These moves were only possible thanks to foreign donor funds.

Membership records for SEWU are difficult to gauge, in retrospect. SEWU had the habit of recording not only paying members but also "lapsed" members, i.e. all those former members who had not paid their dues for six months. When figures are quoted it is not always clear whether reference is to paying members or to a combination of paying and lapsed members (see Motala 2003:30; Devenish \& Skinner 2004:17). In the first three years of existence SEWU grew rapidly to 2,425 in 1997, and another three years later a peak was reached of $3,169^{6}$ members (Devenish \& Skinner 2004:16). In the following year a decline sets in, the depth of which is unclear; one source gives 2,645, another 2,276 members for 2001. At this low point, SEWU reports 10,645 "lapsed" members (Motala 2003:30). From then onwards the picture is ambiguous. Devenish \& Skinner (2006:261) claim that membership rose again to 4,930 in 2003 , but another report speaks of a "dramatic decline in membership in

\footnotetext{
${ }^{6}$ The authors claim that these figures are based on SEWU's annual reports. Motala (quoting the half yearly report for 2001) reports a figure of 3,095 for 2000 (2003:30).
} 
2003" and a financial situation that could only be improved thanks to a reduction of staff in all provincial offices from three to one (Roos 2004:2). At the peak of SEWU existence (in 2003) eight international donors were supporting SEWU with one organisation contributing 65 per cent of its annual budget. ${ }^{7}$ However, at the end of that year all but this one major donor had left. One can imagine that in such a situation annual reports are beautified by an organisation desperately looking for a financial life-line. ${ }^{8}$

Be this as it may, in the beginning of 2004, paid up membership stood at 1,967 and provincial offices were closed. The last remaining donor was by that time dissatisfied with the way in which SEWU and its leadership stumbled from crisis to crisis unable to stop the downward trend. The regional structures do not function properly anymore and also the head office lacks the managerial competence to keep financial administration in order. The nail in SEWU's coffin is reported to have been the ... "a decision of the $\mathrm{CCMA}^{9}$, the effect of which was to reinstate in its employ two dismissed officials. SEWU could simply not afford the cost of the accumulated backpay consequent to this decision" (Theron 2007:252). However, in an interview with a policy advisor of the last remaining donor it was mentioned that the fact that after ten years it had proven to be impossible to establish close working relationships with COSATU was felt as a major disappointment. Coupled to the sorry state of the organisation in 2004 (according to this policy advisor) it was not possible anymore to continue the support in the absence of a strong local partner. ${ }^{10}$ It seems that if COSATU had made a move, it might have been able to safe SEWU!

With her own history in formal trade union movement the founder of SEWU, Pat Horn, had realised how important the relations with COSATU would have been, for

\footnotetext{
${ }^{7}$ In an ILO publication from 2001 it reads: “Members' fees cover only about 5\% of SEWU's costs. The rest of its money comes from international donors, overseas trade unions and foreign governments" (Budlender 2001: 17).

${ }^{8}$ It is more difficult to understand why after the collapse of SEWU authors who should know better also push membership figures for SEWU to mythical heights. Devenish and Skinner at first (2006:261) report a maximum of 4,930 members by the end of 2003, but later write that SEWU had 10,000 members (2007:54). Martha Chen even mentions a figure of 25,000 (Chen et al. 2004: 161).

${ }^{9} \mathrm{CCMA}=$ Commission for Conciliation, Mediation and Arbitration.

${ }^{10}$ Given the amounts involved the donor would have easily been able (and willing) to pick up the costs of the two years salary that the verdict amounted to (interview data 2006).
} 
reasons of worker solidarity and for strategic reasons. As Devenish and Skinner report:

From the beginning the founder stressed that it was strategically necessary to position SEWU and its aims within the broader union movement. This was in fact critical to SEWU securing funding from the international trade union movement. COSATU head office acknowledged SEWU from the outset but ironically only at the time of SEWU's closure did national staff pay much attention to this small union. Prior to this, national SEWU staff expressed much frustration at the numerous meetings they tried to schedule with COSATU head office staff, that were either cancelled or no one arrived (2006:264).

It seems that at one point in time there was rapprochement between SEWU and COSATU when the two shared the same donor and "due to an interest in SEWU by COSATU's former president J. Gomomo. However, this relationship ended when Gomomo left COSATU" (Dlamini 2002:76). Thereafter, according to the same study COSATU gave SEWU the cold shoulder, not even responding to correspondence from SEWU (in Dlamini 2002:77). COSATU shop stewards show disdain for SEWU's representatives and the two SEWU officials also provide a reason for this:

They see SEWU as a sexist union - when you are at meetings they will say 'self employed workers union' and when you correct them they are upset ... some say yes we understand your position but we do not know why you want to be a union, why are you not an ordinary organisation, why are you not including men" and the two officials [with whom the interview was held] add: "They do not think that one day they might be self-employed or might be informal sector workers (in Dlamini 2002:77 78).

Significant for SEWU was the progress it made in providing women leadership. Membership training was an important activity, with activities in skill training directly relevant for its members activities (e.g. sewing or business skills), as well as more general education and training in broader issues (e.g. literacy and English language (Devenish \& Skinner 2004:25-28). These activities were particularly successful in empowering women members. SEWU thus pursued two approaches to serve its members: representation and empowerment. Jan Theron, who labels the latter as "conventional empowerment strategies", queries whether "the pursuit of empowerment and trade union-type demands can be reconciled within one 
organisation" (2007:252). This question will be picked up again in the presentation below of the case of the farm workers organisation Sikhula Sonke.

\section{Grass Roots Trade Unionism: Sikhula Sonke}

Sikhula Sonke was registered as a trade union in December 2004. It is the off-spring of the work done by a NGO, the Women on Farms Project (WFP). By March 2006 it reportedly had 2,500 members (Jara 2006:4), by November 2006 this had risen to 3,336. In March 2008 its website reports a membership of 3,600. ${ }^{11}$ The annual report over 2008 lists a membership of 3,977 (Vehicle 2008:7), while in 2010 a membership of "nearly 5,000" is quoted (White 2010: 674). ${ }^{12}$

Sikhula Sonke organises seasonal farm workers and it is open to male members, but it insists on women leadership "because issues that affect women are largely neglected by mainstream unions" and "because we believe that women must lead the efforts for change in their lives" (Who n.d.:1). It is a membership-based organisation and in the first two years of its existence dues were 8 ZAR per month. This was raised to 15 ZAR at its Congress in September 2006 (interview data 2006). ${ }^{13}$

It wants to operate as a social movement trade union and its focus, therefore, is not only on labour issues, but on "all livelihood challenges of farm dwellers". In this it wants to establish an "integrated approach addressing the full range of farm workers problems" (interview data 2006). Sikhula Sonke sees itself as "...a vehicle for the voices of workers, a school where farm workers are educated and a sturdy house that protects workers" (Who n.d.:1). Sikhula Sonke wants

to improve the living and working conditions of members and their dependants, including the youth and elderly and enhance the status of

\footnotetext{
11 see: http://www.sikhulasonke.org/content/XID1-home.html, accessed 12 March 2008; see also the website of Women on Farms Project at http://www.wfp.org.za/content/XID10-history.html, Accessed 14 January 2008. Additional information was obtained during an interview with the General Secretary in November 2006. In the course of 2009 the URL of Sikhula Sonke changed to www.ssonke.org.za.

12 "drawn from over 200 different farms in ten geographical locations in the Western Cape (White 2010:674).

${ }^{13}$ Calculating the membership fee using figures included in the 2008 annual report (total membership 3,977 and income from membership fees ZAR 140,420) suggest, however, that monthly dues are 3 ZAR (Vehicle 2008:7 \& 37). The report also shows that membership fees account for $6 \%$ of operating and programme costs, the remainder covered by (foreign) grants and donations.
} 
women and protect their interests. It wants to do this through collective bargaining on behalf of its members for improved wages and other working conditions, including housing. And it wants to improve the economic conditions of members by developing work and other economic opportunities. $^{14}$

By 2008 it had twelve branches (Vehicle 2008:9). The Branch Executive holds monthly meetings with farm reps where organisers report on activities. In addition it created farm committees whose members (similar to shop stewards) receive training from Sikhula Sonke. The members elect a 'Resource Agent' who can assist farm workers to deal with their problems. There are weekly forums for organisers where plans are discussed and experiences shared (interview data 2006). From the range of "common problems" Sikhula Sonke identified for farm workers it is clear that indeed it adopts a broad vision. On the one hand there are 'labour issues' like unfair dismissals, unsafe working conditions and non payment of minimum wages or illegal deductions from wages. There is bad housing and intimidation of worker leaders. On the other hand Sikhula Sonke also wants to address the high school drop-out rates, food insecurity, gender based violence and the legacy of alcoholism, which is seen as a most pressing problem (interview data 2006).

The fight against evictions from farms was a main initial focal point of action, and this was broadened later to include legal assistance to workers challenging e.g. dismissals before court or through direct intervention with the employer. Sikhula Sonke also enters into collective agreements with individual farms and it tries to create a platform for farm committees to communicate regularly with employers. There are an increasing number of recognition agreements with farms which sometimes result also in a check-off arrangement. It also meets with individual employers regarding intimidation or the prevalence of alcoholism on their farms - on the latter score it is proud to report some success (interview data 2006).

Fiona White (2010) explains that Sikhula Sonke aims at building a democratic movement that challenges the paternalistic employer-employee relations and the highly unequal gender relations at the farms as well as the unfair labour practices. She

\footnotetext{
${ }^{14}$ Taken from a Sikhula Sonke page on the Women on Farm website: accessed at http://www.wfp.org.za/content/3-who_is_sikhula_sonke.html 1 on 19 March 2008.
} 
concludes: "Sikhula Sonke has made inroads into reducing social inequality between farmers and workers, between women and men and between different races" (2010: 680). However, she also reports that neither the branch meetings nor the meetings of the farm committee are held regularly and that their effectiveness varies. A key reason for this, White argues, is "the lack of organizational experience" (White 2010: 676677).

Together with Women on Farms Sikhula Sonke also engages in collective action and campaigns - it e.g. participated actively in a campaign in 2005 targeting TESCO. As one of its challenges it lists that now bargaining is done on a one-on-one basis and it would like to see the formation of a bargaining council to get all the employers around the table (interview data 2006). It organises training and education sessions for shop stewards to equip them with skills to negotiate, and to give them legal knowledge so that they can represent members in hearings.

Where, in all of this, one could wonder, is COSATU? Wendy Pekeur, the General Secretary of Sikhula Sonke said that a COSATU rep attended the congress in 2006 and praised: "You achieved what not even our affiliate could do" (interview data 2006). More specifically asked about the links with COSATU she explained:

"We're nervous by the politics in COSATU. We are a bit scared, with this support for Zuma, it is confusing. We prefer a non-political trade union." As for affiliation to COSATU she said: "At the moment we want to consolidate...maybe in the future" (interview data 2006).

Fiona White reports that by 2007 the COSATU Western Cape Provincial Secretary claimed to have a "good relationship" with Sikhula Sonke and indeed both organisations shared public platforms e.g. demonstrating against evictions with a march to Parliament in 2007. But this co-operation does not go beyond the recognition of Sikhula Sonke's existence, and possibly some moral support, i.e. no material support (in whatever form) is given. COSATU does not open up its educational programmes to Sikhula Sonke. ${ }^{15}$ COSATU does also not facilitate the

\footnotetext{
${ }^{15}$ This is exactly what the union centre in Zimbabwe has done: accept the organisation of informal workers as an affiliate and invite its members to ZCTU education events. It even has produced a manual for para-legal training for informal workers.
} 
participation of Sikhula Sonke members in the training programmes DITSELA offers. ${ }^{16}$

\section{In Search of Explanations for COSATU's Reluctance}

Despite numerous calls from its own affiliates COSATU as the main national umbrella organisation for labour failed to pick up the gauntlet thrown by globalisation and flexibilisation in the form of ever increasing numbers of vulnerable workers. Reasons for this reluctance could be numerous. A first clue could be found if one realizes that there is an ever growing gap between earnings of union members and non-members. An analysis of trends in fifty wage settlements in collective agreements of eight sectors in 2006/7 show average monthly salaries of ZAR 8,500 (Ndungu 2007:5-7), with incomes in the informal economy well below 2,000 ZAR. An earlier survey showed that the average income for COSATU members was one-and-a half times the income of non-members (Naledi 2006: 55). Further, union members stood a better chance of receiving benefits such as medical aid, retirement fund, paid leave and a written contract of employment.

So, it could well be that union members affiliated in COSATU are more and more distancing themselves from the working poor. However, this is not very likely. On the one hand, every wage earner maintains up to five dependents, and so the reality of livelihood struggles is vividly present in almost every household. On the other hand, COSATU affiliates do try and reach out to vulnerable workers, whether in the formal of informal sectors. Affiliates are attempting to organize in their respective sectors construction workers, casual shop workers, industrial home workers minibus drivers, security guards and cleaning workers (see Horn 2008:4). It is COSATU itself -as a national centre - that does not make a move. An explanation for this could be inspired by the sociological theory of opportunism, suggested by Offe and Wiesenthal (1985). The argument is that a trade union at a certain stage of its development depends for its continued success on openings offered by the state rather than on extending and

\footnotetext{
${ }^{16}$ DITSELA is the Development Institute for Training, Support and Education for Labour, formed by the labour movement and the Ministry of Labour in 1996 and is highly regarded for its quality education and training it offers. Although created to serve the whole labour movement in South Africa COSATU tends to see it as an "extension of its own education department over which it has exclusive control (see Schiphorst et al. 2007:58).
} 
mobilising its membership base. COSATU leadership seems so keen on its position within the tri-partite alliance and the influence this has yielded in many a tripartite national forum that it neglects calls for an organisational renewal.

Not that these calls are easy to heed. Jan Theron recently referred to a 'wage culture' which now blocks the emergence of solidarity (2010:88). Such a wage culture not only locks the established trade unions in a logic of collective action which is only focussed on collective bargaining. Dealing with vulnerable workers (a substantial part of who are not wage workers but basically entrepreneurs) then not only becomes an ideological anathema, but would also require a behavioural split. Theron argues for a paradigm shift because "the prospect of waged employment is increasingly unrealistic for ever larger numbers". Such a paradigm shift should render membership-based organisations again meaningful for the poor (ibid.; Theron 2005).

A glimmer of hope could be found in the approach which makes especially Sikhula Sonke successful. It has a broad agenda, and uses a wide array of approaches: collective action and individual mediation, through representation as well as membership empowerment. Contrary to Theron's fears (see Theron 2007:252) such a combined approach is not only possible for a trade union but seems also to be successful for union and members alike. It could well be, though, that it is especially this combination of representation and empowerment that makes it difficult for COSATU to follow locked as it seems to be in an exclusive representational mode. A mode that is focussed at representation at national levels at the expense of local levels.

\section{Conclusion}

The paper has examined the approach of COSATU towards vulnerable workers, both as informalised workers linked to the formal sector as well as workers engaged in informal work. The record of the federation is not positive. Despite numerous resolutions at its national congresses COSATU seems to face major internal hurdles to get something off the ground. This could be partly because of the problems inherent in engaging with vulnerable workers, partly because of an inclination to deal first and foremost with the formal sector. It would seem that a rejuvenated commitment is required for the national centre to take up the plight of the vulnerable workers. 
The comparison between COSATU on the one hand, and on the other hand SEWU and Sikhula Sonke -two cases of organising for vulnerable workers-shows that a combination of different modes of collective action (representation and empowerment) seems to offer changes for success. In SEWU's case COSATU's absence contributed to its downfall. What COSATU's arm's length practice will mean for Sikhula Sonke is something the future only will tell. However, with a more prominent role in collective bargaining in the future it would seem that a partnership of some sorts would allow the negotiators of Sikhula Sonke to draw on the vast experience of COSATU in this respect. Such a partnership could be mutually valuable in that COSATU could learn to broaden its range of collective action modes to include empowerment strategies. And from this, so it seems, vulnerable workers in whose ranks have grown so dramatically after the crisis hit South Africa could benefit. 


\section{References}

Adu-Amankwah, Kwasi (1999) "Trade Unions in the Informal Sector: Finding Their Bearings: Nine Country Papers: Ghana." Labour Education No. 116, 1999/3: 114.

BCEA (1997) Basic Conditions of Employment Act (No 75 of 1997). Accessed at http://www.labour.gov.za/download/5109/Act\%20\%20Basic\%20Conditions\%20of\%20Employment.pdf on 4 March 2008.

Bennet, Mark (2003) Organizing in the Informal Economy: A Case Study of the Clothing Industry in South Africa. Seed Working Paper No. 37. Geneva: International Labour Office. Downlaod at http://www.streetnet.org.za/English/wp37-2003.pdf accessed 27-03-2005.

Bonner, Chris (2004) Organisational Renewal in COSATU \& Affiliates: An Overview. Johannesburg: NALEDI. Accessed at http://www.naledi.org.za/docs/OrgRenewal1104.pdf on 5 March 2008.

Budlender, Debbie (2003) Street Traders and their Organisations in South Africa. Geneva: International Labour Office.

Chen, Martha Alter \& Joann Vanek \& Marilyn Carr (2004) Mainstreaming Informal Employment and Gender in Poverty Reduction: A Handbook for Policy-Makers and Stakeholders. London: Commonwealth Secretariat.

COSATU (2006) "COSATU Secretariat Report to the Ninth National Congress to be held on 18 to 21 September 2006, Gallagher Estate, Midrand." Accessed at http://llnw.creamermedia.co.za/articles/attachments/03082_cosatusecreta.pdf on 4 August 2008.

Devenish Annie \& Caroline Skinner (2004) "Organising Workers in the Informal Economy: The Experience of the Self Employed Women's Union, 1994-2004.” School of Development Studies, University of KwaZulu-Natal August 2004. Download at http://www.wiego.org/publications/Devenish\%20and\%20Skinner\%20Organizin g\%20Workers\%20in\%20the\%20IE.pdf. Accessed 12-02-2008.

Devenish, Annie \& Caroline Skinner (2006) "Collective Action in the Informal Economy: The Case of the Self-Employed Women's Union, 1994-2004." In Richard Balland, Adam Habib \& Imraan Valodia (eds.) Voices of Protest: Social Movements in Post-Apartheid South Africa, 255-77. Scottsville: University of KwaZulu-Natal Press.

Devenish, Annie \& Caroline Skinner (2007) "SEWU and Sikhula: Tips on Organising Informal Workers." South African Labour Bulletin 31(3): 56.

Dlamini, A. (2002) "Mainstreaming the Informal Economy in South Africa: A Gender Perspective of Trade Union Policy responses (1994-2001)." Mini-Dissertation. Johannesburg: Rand Afrikaans University. Accessed at http://ujdigispace.uj.ac.za:8080/dspace/bitstream/10210/101/1/Draft1.pdf 4 March 2008.

Final (2009) "Final Draft Consolidated Resolutions to the COSATU $10^{\text {th }}$ National Congress." Accessed at on February 7, 2010

Goldman, Tanya (2003) Organizing in South Africa's Informal Economy: An Overview of Four Sectoral Case Studies. SEED Working Paper No. 60. Geneva: International Labour Office. Accessed at http://www.wiego.org/program_areas/org_rep/Goldman\%20overview\%20of\%2 04\%20sectoral\%20studies.pdf on 28 February 2008. 
Gordhan, Pravin (2010) Budget Speech 2010: Minister of Finance, 17 February 2010. Pretoria: National Treasury. Accessed at www.treasury.gov.za on 15 September 2010.

Horn, Pat (2005) "COSATU Strategic Planning Workshop: Organising Workers in the Informal Economy." StreetNet News 5. Accessed at http://www.streetnet.org.za/englsih/cosatu5.htm on 7 July 2006.

Horn, Pat (2008) "Realising Decent Work in Africa: A Shared Vision of Growth and Improved Quality of Life in a Globalized World." Paper prepared for the $5^{\text {th }}$ African Regional Conference of the IIRA, 26-28 March 2008, Cape Town.

Jara, Mazibuko K. (2006) Monitoring Compliance with the Sectoral Determination for Farm Workers in Five Westerns Cape Farming Districts: Report of an Exploratory Study. Stellenbosch: Women on Farm Project. Accessed at http://www.wfp.org.za/pdf/compliance_to_sectroral_determination_for_farm_w orkers_5_wes.pdf, on 14 January 2007.

Kabeer, Naila (2008) Mainstreaming Gender in Social Protection for the Informal Economy. London: Commonwealth Secretariat.

Kalula, Evance (2006) "Employment Conditions Commission. $11^{\text {th }}$ Nedlac Summit." Accessed at http://www.nedlac.org.za/summit/2006/ekalula.pdf on 3 March 2007.

King, Alison Jill (2007) Domestic Service in Post Apartheid South Africa: Deference and Disdain. Aldershot: Ashgate.

Kragtwijk, Trudy (2004) Report SEWU Mission, Durban South Africa 21-27 April at the Request of FNV Mondiaal. Purmerend: Baobab Development Services.

Lund, Francis and Skinner, Caroline (1999) Promoting the Interests of Women in the Informal Economy: An Analysis of Street Trader Organisations in South Africa. CSDS Research Report No. 19. Durban: School of Development Studies, University of KwaZulu-Natal. Downlaod at http://sds.ukzn.ac.za/files/rr19.pdf accessed 25.05.2007

Lund Francis and Skinner, Caroline (2004) "Integrating the Informal Economy in Urban Planning and Governance: A Case Study of the Process of Policy Development in Durban, South Africa." International Development Planning Review, 26(4): 431-456.

Mitlin, Diana \& Jan Mogaladi (2009) "Social Movements and Poverty Reduction in South Africa." Working Paper in the Research Programme Social Movements and Poverty in Peru and South Africa. Manchester: School of Environment and Development, Manchester University. Accessed at http://www.sed.manchester.ac.uk/research/socialmovements/publications/report s/Mitlin_Mogaladi_SouthAfricamappinganalysis.pdf on 3 October 2010.

Motala, Shirin (2002) Organizing in the Informal Economy: A Case Study of Street Trading in South Africa. SEED Working Paper No. 36. Geneva: International Labour Office.

Naledi (2006) The State of COSATU: Phase One Report. August 2006. Accessed at http://www.naledi.org.za/pubs/2006/The_state_of_Cosatu_Report.pdf on 4 March 2008

Ndungu, Simon Kimani (2007) "Surviving Below the Margin: Recent Trends in Collective Bargaining and Wage Settlements." Naledi Policy Bulletin 8(2):4-8. Accessed at www.naledi.org/pubs/2007/Collective_Bargaining.pdf on 29 October 2007.

Ndungu, Kimani (2009) Labour Brokers: Should They be Banned or Regulated? Naledi Research Working Report Vol 1, No. July 2009. Johannesburg: Naledi. 
Offe, Claus \& Helmut Wiesenthal (1985) “Two Logics of Collective Action.” In Offe, Claus Disorganized Capitalism, 170-220. Cambridge: Polity Press. First published in 1980.

Organisational (2003) Organisational Review report to the 8th National Congress. COSATU. Accessed at http://www.cosatu.org.za/cong2003/congweb/Org.pdf on 2 March 2008.

Report (2003) Report of the Employment Conditions Commission: 1 August 1998 - 31 March 2003. Pretoria: Department of Labour. Accessed at www.labour.gov.za. on 28 February 2008.

Roos, Wilma (2004) "Notitie: SEWU in Trouble." WOM/TOP. FNV Mondiaal, Amsterdam. Mimeo.

Robinson, Vickie (2005) "COSATU to launch new union." Cosatu Weekly 15 July 2005. Accessed at www.cosatu.org.za/news/weekly/20050715.htm on 15 February 2008 .

Schiphorst, Freek B. (2001) "Strength \& Weakness: The Rise of the Zimbabwe Congress of Trade Unions and the Development of Labour Relations, 19801995." Ph.D. Thesis, University of Leiden, Leiden.

Schiphorst, Freek B.; G. Farred \& T. vd Rijk (2007) Country Report South Africa: Evaluation Trade Union Co-Financing Programme. The Hague: Inspectie Ontwikkingssamenwerking en Beleidsevaluatie (IOB), Ministry of Foreign Affairs. Accessed at http://www.minbuza.nl/binaries/en-pdf/iobevaluatie/bijlagen/rapport-309/countryreport-south-africa--english-.pdf on 4 August 2008.

September Commission (1997) The Report of the September Commission on the Future of the Unions to the Congress of South African Trade Unions, August 1997. Accessed at http://www.cosatu.org.za/congress/septcomm.htm\#intro on 16 March 2008.

Skinner, Caroline (2000) Securing Livelihoods: A Gendered Analysis of Support Interventions Available to Street Traders in the Durban Metropolitan Area. CSDS Research Report No 34. Durban: University of KwaZulu Natal. Accessed at http://sds.ukzn.ac.za/files/rr34.pdf on 22 April 2007.

Statsa (2009) Statistical Release P0211: Quarterly Labour Force Survey Quarter 1, 2, $3 \& 4$ 2009. Pretoria: Statistics South Africa. Accessed at www.statssa.gov.za on 24 April 2010.

Statsa (2010) Statistical Release P0211: Quarterly Labour Force Survey Quarter 1 \& 2, 2010. Pretoria: Statistics South Africa. Accessed at www.statssa.gov.za on 29 August 2010.

Theron, Jan (2005) "Employment is not What is Used to Be : the Nature and Impact of Work Restructuring in South Africa." In Webster, Edward \& Karl von Holdt (eds.) Beyond the Apartheid Workplace: Studies in Transition, 293-316. Scottsville: Unievrsity of KwaZulu-Natal Press.

Theron, Jan (2007) "Membership-Based Organizations of the Poor: The South African Experience." In Martha Chen; Renana Jhabvala; Ravi Kanbur \& Carol Richards (eds.) Membership-Based Organizations of the Poor, 240-60. London: Routledge.

Theron, Jan (2010) "Informalization from Above, Informalization from Below: The Options for Organization." African Studies Quarterly 11 (2 \& 3): 87-105.

Vavi, Zwelinzima (2010) "Address to the National Farm workers Summit 30-31 July 2010 in Somerset West.” Accessed at 
http://www.cosatu.org.za/show.php?include=docs/pr/2010/pr0730a.html\&ID=36 73\&cat=COSATU\%20Today on 10 October 2010.

Vehicle (2008) A Vehicle for Women's Voice to be Heard: Annual Report 2008 Sikhula Sonke. Accessed at http://www.ssonke.org.za on 12 September 2010.

Verick, Sher (2010a) Unravelling the Impact of the Global Financial Crisis on the South African Labour Market. Employment Working Paper No. 48. Geneva: International Labour Office.

Verick, Sher (2010b) "The Global Financial Crisis and South Africa: What has been the Impact on the Labour Market?" Paper prepared for the

White, Fiona (2010) 'Deepening Democracy: A Farm Workers' Movement in the Western Cape.” Journal of Southern African Studies, 36 (3): 673-691.

Who (n.d.)"Who We Are." Sikhula Sonke Project. Accessed on http://sikhulasonke.org/content/XID2-who-we-are.html on 12 March 2008.

Zimbabwe Congress of Trade Unions (2005) The Decent Work Agenda and the Role of Trade Unions: Zimbabwean Case. Harare: Zimbabwe Congress of |Trade Unions.

\section{Interviews}

Wendy Pekeur, General Secretary Sikhula Sonke, 4 November 2006, Cape Town.

Elijah Mutemeri, Informal Economy Programme Coordinator, ZiCTU, 22 February 2010, Harare.

Vimbai Mushongera Zinyama, Parliament, Advocacy \& International Affairs (previously Informal Economy Programme) ZiCTU, 22 February 2010, Harare.

Miriam Chikamba, Head Education Department, ZiCTU, 24 February 2010, Harare. 